\title{
Exploring parent and student engagement in school self-evaluation in four European countries
}

European Educational Research Journal 2021, Vol. 20(2) 159-175

(C) The Author(s) 2020

Article reuse guidelines: sagepub.com/journals-permissions DOI: $|0.1| 77 /|474904| 2096 \mid 203$ journals.sagepub.com/home/eer

\section{Martin Brown}

\section{Gerry McNamara}

Centre for Evaluation, Quality and Inspection (EQI), Dublin City University (DCU) Institute of Education, Ireland

\section{Sakir Cinkir}

Department of Educational Administration and Policy, Ankara University, Turkey

\section{Jerich Fadar}

Department of Training and Education Science, University of Antwerp, Belgium Flanders

\section{Maria Figueiredo}

School of Education, Polytechnic Institute of Viseu, Portugal

\section{Jan Vanhoof}

Department of Training and Education Science, University of Antwerp, Belgium Flanders

\section{Joe O'Hara}

\section{Craig Skerritt}

\section{Shivaun O'Brien}

Centre for Evaluation, Quality and Inspection (EQI), Dublin City University (DCU) Institute of Education, Ireland

\section{Gül Kurum}

Department of Educational Administration and Policy, Ankara University, Turkey

\section{Henrique Ramalho}

\section{João Rocha}

School of Education, Polytechnic Institute of Viseu, Portugal

\section{Corresponding author:}

Martin Brown, Centre for Evaluation, Quality and Inspection (EQI), School of Policy and Practice, DCU Institute of Education, Dublin 9, Ireland

Email. martin.brown@dcu.ie 


\begin{abstract}
The purpose of this paper, which is part of a three-year EU Erasmus +-funded study titled 'Distributed Evaluation and Planning in Schools' (DEAPS), is to provide an analysis of policies, structures, processes, supports and barriers that exist to enable or inhibit the involvement of students and parents in school evaluation in four European countries (Belgium, Ireland, Portugal and Turkey). Document analysis was used for this study and some 348 peer-reviewed articles, and 28 national and transnational policy documents were included in the analysis. Based on this review it would be reasonable to suggest that the student/parent voice agenda around evaluation in schools remains, by and large, aspirational. It is extolled in policy but in practice is mainly tokenistic with very little evidence of impact on the work of schools. In light of this, it is argued that government and schoollevel policies and strategies need to be reconsidered to enhance students' and parents' engagement in school evaluation. As a first step, significant further empirical research on the limitations on and conditions necessary for stakeholder voice in education is required.
\end{abstract}

\title{
Keywords
}

Inclusion, school self-evaluation, stakeholder voice, partnerships, inspection

\section{Introduction}

The decentralisation of governance and the consequent drive to more actively include citizens in decision-making processes have become part of the discourse of public sector 'reform' in most European countries particularly in services such as healthcare and education (Beckmann et al., 2009; Verger and Curran 2014). This policy direction can, it is suggested by its proponents, serve a variety of purposes such as reducing state bureaucracy, improvement of services by both regulation and competition, and enhanced 'stakeholder' voice and choice (Brown et al., 2016a). In the education sector, for example, while accountability through the process of school inspection has become emphasised in most Organisation for Economic Co-operation and Development (OECD) countries, inspection models have matured and been adapted as educational evaluation systems mature. In theory, it is argued, as schools and their stakeholders develop evaluation literacy and innovation capacity to improve education in their organisations, they have less need of being driven by top-down inspections and reform initiatives. This trend has resulted in the gradual emergence of a dual system of participatory internal/external school evaluation that is now being employed in many OECD countries (Santiago, 2013). In theory, at least, most emerging systems of both inspection and internal school evaluation stress the importance of giving 'stakeholders', in particular students and parents, a significant role in the process. Such involvement is a key strategy in achieving support and commitment among stakeholders for change and improvement (Adelman and Taylor, 2007) and it also builds a more inclusive school community (Carrington and Robinson, 2006).

This paper begins by looking at the emergence of external evaluation/ inspection, usually linked with some form of internal evaluation, as a common mode of school governance in many education systems and explores the growing theoretical emphasis on student and parent voice in both elements of the process. The paper then proceeds to examine policy and practice concerning student and parent involvement in both external and internal or school self-evaluation as it is commonly known in four European countries (Belgium, Ireland, Portugal and Turkey).

The choice of countries for the research was based on a theoretical sampling strategy (Kelle and Kluge, 2010) that allowed for an exploratory analysis of a wide variety of school evaluation systems contained within the European Educational Policy space. On the one hand, while each 
country involved in the analysis has long-established mechanisms to initiate school inspection, allowing for sampling diversity, the extent to which schools in each of the case study countries initiate and have in place mechanisms for school self-evaluation varies considerably. Analysis of school leaders reports derived from the Programme for International Student Assessment (PISA) in 2015 reveals that 'all school leaders in Ireland are expected to conduct self-evaluations of their schools' (OECD, 2019: 395). Compared to the OECD average, 'school leaders in Portugal are more likely than average to conduct self-evaluations' (470). In the case of Turkey, school leaders 'are about as likely as the OECD average to conduct self-evaluations of their schools' (517). In Belgium, 'school leaders in Belgium are less likely than the (OECD) average to conduct selfevaluations of their schools' (281).

Finally, although the levels of parent/student engagement in the evaluation process should in some way be affected by the frequency and mechanisms of school evaluation that exist, it is suggested that there is also a considerable gap between rhetoric and reality in these cases. The study concludes with a discussion of key challenges for stakeholder voice in educational evaluation and argues that in the absence of clearly defined strategies to address the 'stakeholder gap', progress will probably remain slow - yet another stifled educational reform initiative.

\section{School evaluation and student/parent voice}

School evaluation is used to investigate how successfully in-school activities such as teaching and leadership are performed by schools (Donaldson, 2013). For this purpose, many countries have developed models of school inspection to monitor and evaluate the quality and efficacy of various aspects of education and also to provide recommendations for improvement (Santiago, 2013). However, this has not always been the case. For much of the 20th century, dominated by scientific management theory, inspection oversight had a controlling mentality. Inspection was described as controlling human behaviour for the benefit of the organisation (Taymaz, 2013: 3). Over time, however, this controlling mentality changed, and now inspection is quite frequently perceived as primarily supportive and developmental (Aydin, 2013). This occurs through thematic or risk-based inspections (Katipoğlu, 2016) and school self-evaluation (SSE) (Brown et al., 2018; Young et al., 2018; Çınkır, 2014; European Commission, 2015). Instead of defining inspection as limited to oversight and compliance with given policies and legal requirements, it is frequently discussed in terms of what support inspection can provide for educational organisations, principals and teachers to perform their jobs more effectively (Carroll, 2007). School inspection has evolved, in many countries, into a collaborative process in which educational stakeholders such as principals and teachers take part. Inspection outcomes can, therefore, be described as a 'collective vision for highquality education that is developed by inspectors, teachers, and other school employees' (Glickman et al., 2014: 8).

However, it is increasingly recognised that because evaluation at its best can help to distinguish and promote good examples, identify weaknesses and hold schools accountable to stakeholders such as students and parents (Hooge et al., 2012) it makes sense that these actors are also given a voice in the evaluation process. Building a democratic society requires democracy at all tiers of the system. In a consensus-based democratic educational context, key stakeholders should be given both the right and the responsibility to be involved in the school improvement process (Gordon and Seashore Louis, 2009). However, this is nice in theory but, in practice, as these stakeholders appear to be granted a more active role in school evaluation, in reality parents and students can find themselves limited to very constricted and tokenistic roles and degrees of participation. This is well illustrated by Hart's (1992) Ladder of participation (Table 1). 
However, the varying Degrees of Non-Participation as described by Hart (1992) may not always be a deliberate and intended strategy to exclude parents and students from evaluation and planning processes. Internal evaluation, or school self-evaluation (SSE) as it is known in many countries, can have implementation challenges (Brown et al., 2017; O'Brien et al., 2019), particularly where the role of parents and students is concerned (Brown, 2013; Verger and Curran, 2014;). The existing body of literature about school evaluation has mainly focussed on capacity-building for school leaders and teachers (Brown et al., 2017; McNamara and O'Hara, 2012; Vanhoof et al., 2009). Although it is critical to address the capacity challenges of all stakeholding groups, there is a scarcity of research relating to methods of evaluation and policy-implemented strategies and supports that specifically focus on the voice of other members of the school community as active participants in external evaluation and SSE. To address this lacuna, this paper, as part of a three-year European Commission Erasmus + project, provides a comparative analysis of what we refer to as Distributed Evaluation and Planning Strategies (DEAPS) in the four European countries in question.

The concept of DEAPS, in this case, refers to the roles of students and parents in school evaluation both external and internal and in formulating and monitoring plans for improvement which is invariably an element of all evaluation regimes. To explore this further, national and school-level evaluation policy documents, structures and processes in each country are described. Actual realities are then compared to policy rhetoric by considering emerging DEAP practices, barriers and supports.

\section{Research method}

This research formed part of a broader study that sought to investigate and develop mechanisms to support schools with the inclusion of parents and students in the process of school evaluation and consisted of a number of distinct phases. Using document analysis as the research frame, the first phase of the study consisted of a document analysis of policy documents relating to the strategies and supports for the inclusion of parents and students in evaluation in each of the partner countries.

According to Bowen (2009), document analysis has various purposes. It provides information about the background of the research subject. However, it can also be used to track 'change and development, and verification of findings from other sources' (30). To ensure authenticity and reliability of the data to form overarching themes for the analysis, inclusion of documents was limited to official government policies, school-level documents on school evaluation that have been published since the year 2000. Twenty-eight policy documents were used for the final analysis. This process of analysis allowed the researchers to form an overall interpretation of the study in which country comparisons are presented in cross-tables, taking into account the main themes that arose from the search (Table 1).

Following on from this, the EndNote software program was used to search for peer-reviewed journal papers on the barriers and supports for the integration of parent and student voice in evaluation that were written in the English, Dutch, Portuguese and Turkish languages. This phase of the research used an integrated library and online search mode that was applied to various educational databases. The databases investigated included Web of Science, Education Research Complete (EBSCO), ERIC, JSTOR, Scopus, Social Science Premium Collection (ProQuest) and OECDiLibrary. The first search cycle using the terms 'Parent and Student Voice' and 'Stakeholder voice in Evaluation' yielded a wide range of topics and sources with limited results that specifically related to the inclusion of parents and students in school evaluation. However, in the second search cycle, terms were narrowed to 'Barriers and Supports' and Parent and Student Voice in Schools'.

After a process of data crystallisation and immersion (Borkan, 1999), the second search resulted in 384 full-text scientific papers. However, 36 papers were not directly related to stakeholder voice 
Table I. The ladder of participation (Hart, 1992).

Degrees of

participation
8. Students/parents-initiated, students/parents shared decisions with adults

7. Students/parents-initiated, students/parents-led decisions

6. Adult-initiated shared decisions with students/parents

5. Students/parents are informed and consulted

4. Students/parents are informed and assigned

Degrees of non-participation
3. Students/parents are tokenised

2. Students/parents are decoration

I. Students/parents manipulated

and school evaluation. For this reason, 348 papers were used for the final analysis that is presented in the following sections of this paper.

\section{National DEAP strategies and supports in case study countries}

There are differences and similarities relating to stakeholders' participation in SSE at each level of each country's education system (Table 2). These levels can be grouped into system, regional and school/institution levels.

Central-level DEAP indicators in Belgium (Flanders). The Belgium (Flanders) education system allows all school types significant independence in terms of school evaluation. The Ministry for Education and Training oversees how effectively schools, and the education system in general, are meeting the attainment targets and development objectives set by the government. However, due to the very substantial autonomy enjoyed by schools, they and their teachers have a central role to play in quality assurance and school evaluation. Indeed, SSE, is not mandatory in Belgium (Flanders) and how and if schools conduct such internal evaluations is not stipulated by the government (Vanhoof et al., 2011).

In Belgium, schools are autonomous in terms of defining and improving the quality of education. Based on this autonomy, schools and teachers have a central importance regarding school evaluation and quality assurance. In principle, while schools are not obliged to carry out SSE, they are, however, responsible for improving the quality of education (Faddar and Vanhoof, 2018).

Also, in Belgium (Flanders), to encourage different voices to participate in policymaking in schools, there are some unregulated initiatives. One of these initiatives is the strategy of 'collegial' visits. This strategy bridges SSE with aspects of external evaluation. In this process, a team of teachers from other schools visit a school to provide advice for further development based on their professional judgement (Cautreels and Van Petegem, 2006). As part of this process, in order to include stakeholders' voice, the external team can consult representatives of different groups to help inform the advice they offer (Hannes and Vanhoof, 2017).

Central-level DEAP indicators in Ireland. In Ireland, at the primary and post-primary level, a dual mode of evaluation has been developed, which includes external inspection and SSE. The role of the inspectorate of the Department of Education and Skills (DES) is described as being 'to evaluate the education standards in such schools or centre in order to promote excellence in the management of, teaching in and the use of support services by schools' (Education Act, 1998). The DES inspectorate evaluates Irish schools in accordance with the 1998 Education Act. External school inspection, which has developed iteratively over the past 20 years, now offers a range of models of inspection, all of which focus on the quality of teaching, learning and leadership in the school but each with a slightly different focus. These models of inspection include Incidental Inspection, 


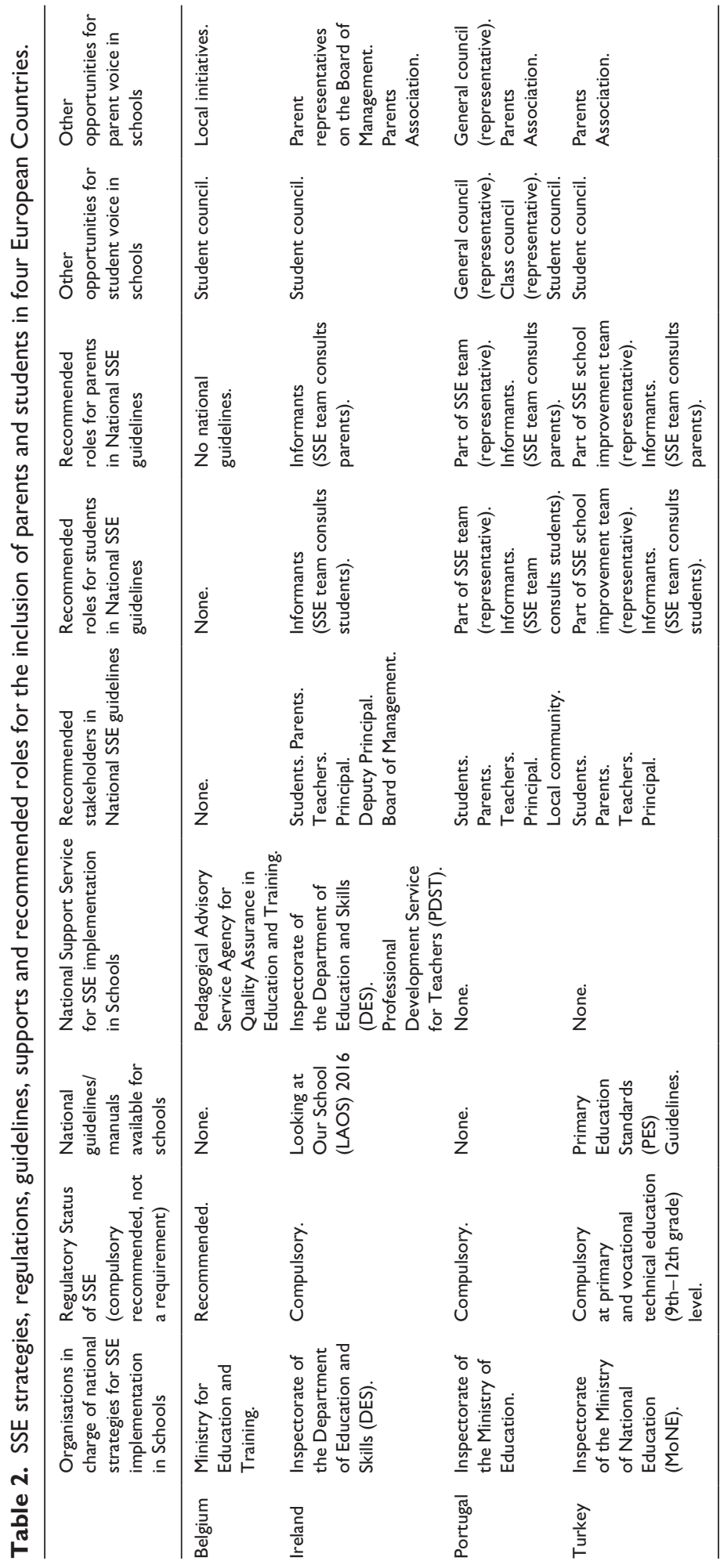


Subject Inspection, Programme Evaluation, Evaluation of Action Planning for Improvement in DEIS (Delivering Equality of Opportunity in Schools - designated disadvantaged schools) Schools, Whole-School Management, Leadership and Learning, Whole-School Evaluation, and followthrough Inspection (DES, 2016). In parallel, inclusive of parents and students, primary and postprimary schools are also legislatively required to carry out SSE in the form of internal evaluations of a particular aspect of teaching and learning using evaluation guidelines and criteria developed by the inspectorate of the DES (DES, 2012a, 2012b).

Central-level DEAP indicators in Portugal. The education system in Portugal mandates for schools organisational evaluations that emphasise improvement and development more than accountability. Law no. 31/2002 established the system of evaluation of pre-school, primary and secondary education establishments, defining complementary guidelines for SSE and school external evaluation. The same system of inspection is implemented in public and private schools. SSE is compulsory in Portugal. It is an instrument whereby the school's progress is examined through an annual written report on educational activities and management effectiveness (Law no. 31/2002). SSE also forms the basis for external school evaluation which is carried out periodically by teams formed by the Inspectorate-General of Education and Science (IGEC) together with external experts (Figueiredo et al., 2018). There is no inspectorate recommended model for SSE. Schools can choose between available frameworks or develop their own. However, Law no. 31/2002 establishes the dimensions to be evaluated: teaching and learning activities, referenced to the educational project of the school; social and emotional conditions for learning; leadership; academic success; and collaboration between all members of the educational community. Since the dimensions and indicators are compulsory and the external evaluation team has a clear model, a soft orientation/regulation was identified in the previous cycles of evaluation with schools using the External Evaluation framework for their self-evaluation (Sousa and Terrasêca, 2015). In the latest cycle (2011-2017), specific tools have been made available for SSE, namely surveys for parents and students.

Central/regional-level DEAP indicators in Turkey. The Turkish Education System is managed by the Ministry of National Education (MoNE) who are responsible for school inspections at the preschool/primary education level. These inspections are conducted in accordance with Regulation for the Board of Inspectors and Offices of Educational Inspectors of MoNE (MoNE, 2014). Secondary schools, on the other hand, are not inspected by the MoNE, and instead, internal inspections (including classroom observations) are conducted by the management of the school. SSE, on the other hand, is not compulsory in Turkey. Opinions are sought as part of both Primary Educational Institutional Standards (PEIS) and external inspection through the use of surveys which parents and students are invited to complete.

\section{Regional-level DEAP indicators}

From a governance perspective, Ireland and Belgium are very centralised systems while Portugal and Turkey have intermediate structures between central government and schools.

Portugal and Turkey structure educational inspection at a regional or local level. In the case of Portugal, education financing has been devolved from the central level to the municipality, for the primary level. In addition, the municipality has also been put in charge of the management of training projects and the management of non-teaching staff.

In Turkey, there are Directorates of National Education, responsible for education at the regional level. These provide communication and coordination between the central government and the 
schools (Başaran and Çınkır, 2013). Directorates of National Education in Turkey serve the provincial and district levels. The task of these units is to ensure that the objectives of national education policy are realised as well as analysing differences in student achievement among schools. Support is also provided to principals and teachers to solve improvement issues that are highlighted in school inspection reports (MoNE, 1995).

\section{School/institution-level DEAP indicators}

As argued earlier in this paper, external school inspection, often linked to some form of SSE, has become a significant component of school governance in many countries, even those with little or no tradition of inspection. Integral to most such inspection regimes is a recognition that parent and student voice ought to be a central concern of school evaluation. Nearly all policy documents make glowing reference to the roles of these stakeholders and include strategies to include them. However, the reality can fall short of the rhetoric.

School/institution-level DEAP indicators - Belgium. In Belgium, schools are autonomous in terms of defining and improving the quality of education. Based on this autonomy, schools and teachers have a central importance regarding school evaluation and quality assurance. In principle, while schools are not obliged to carry out SSE, they are, however, responsible for improving the quality of education (Faddar and Vanhoof, 2018). School councils enable parents, staff, the local community and, in secondary education, students to participate in policymaking with an equal amount of representatives. The school council is a body that provides the school governing board with advice on the role of the school leader, the staff professional development plan and collaboration with other schools or external partners. Student councils also exist and are an advisory body that aims to enhance the dialogue between students and the school management and teachers. Also, in Belgium (Flanders), to encourage different voices to participate in policymaking in schools, there are some 'unregulated initiatives. One of these initiatives is the strategy of 'collegial' visits. This strategy bridges SSE with aspects of external evaluation. In this process, a team of teachers from other schools visit a school to provide advice for further development based on their professional judgement (Cautreels and Van Petegem, 2006). As part of this process in order to include the stakeholders' voice, the external team can consult representatives of different groups to help inform the advice they offer (Hannes and Vanhoof, 2017).

School/institution-level DEAP indicators - Ireland. School administrators, teachers, students and parents are regarded in theory as the key stakeholders in the context of SSE. However, consulting students or asking for their opinions is not common in Irish schools (Fleming, 2011). The main platform for students to formally engage in school decision-making is through student councils, but while the vast majority of schools do have student councils, not all schools do (Darmody and Smyth, 2013). For students, as Fleming (2015: 235) reports, the reality of the council, and consequently the student voice, is one of 'tokenistic activity, contrived involvements with decisionmaking, and a significant focus on school event organisation or charity fundraising'. In terms of parent involvement, even after the establishment of parent councils, the home-school-community liaison scheme, the improved representation of parents on boards of management, and the emphasis on 'partnership' in policy documents in recent years, there is little evidence to suggest that the real level of parent involvement has improved to any significant extent (Fleming, 2016). Based on reports by principals, the average level of parental participation in Irish schools is lower than the international average (Cosgrove and Gilleece, 2012). While Irish parents do have a high level of informal involvement in their child's education, collaboration is less well developed on a 
formal level and typically involves them acting in a passive or reactive role (Byrne and Smyth, 2011). Formal parental involvement remains limited in Ireland with few playing an active role either on the board of management or in the parents' association (Gilleece and Eivers, 2018) and while it would appear that although the opportunity for students to get involved in decisionmaking processes in Irish schools is well below the international average despite students in Ireland valuing participation (Cosgrove and Gilleece, 2012), there have been suggestions that it might well be the case that Irish parents would not want to engage with schools on a more formal level, even if opportunities were provided (Skerritt, 2019a). It would appear that the 'legacy of leaving education to others, originally to the Church, but now to school management and teachers, persists to a great degree' (Fleming, 2016: 377), shaping how many teachers and parents feel about the formal involvement of parents today (Skerritt, 2019b). Nonetheless, student and parent voice, through the use of questionnaires and focus group interviews, now form a component of Ireland's school inspection policy and, according to the chief inspector of education in Ireland, the time has finally come to make much greater use of this resource which has remained peripheral to date (Hislop, 2017).

School/institution-level DEAP indicators - Portugal. In the Portuguese education system, there has always been a place for student and parent participation. Since 1974, parental associations have been officially encouraged as a form of parent participation. A 'general council', for the school or a cluster of schools, is responsible for defining the guidelines for school activities and ensuring representation and participation of the school community as well as choosing the president of the council. The general council consists of instruction and support personnel, families, students, local authorities and social organisations (scientific, cultural, economic). In addition to the general council, student and family participation is provided through associations (parents and students) and classroom councils. These councils are shaped according to the class level. The classroom councils consist of all the teachers of the class, two parents and one student representative. This council is responsible for establishing good communication and a partnership between the school and families. In addition, families have the responsibility of overseeing the progress of their children in school (behaviour, discipline, education and training). In this context, families are informed about the status of students through parent-teacher meetings (Figueiredo et al., 2018).

School/institution-level DEAP indicators - Turkey. In Turkey, family and student participation is more limited when compared with the other three partner countries. This is primarily because the role of parents and students in educational decision-making is not legally defined. This complicates participation in the education and training processes. However, even though student and parent participation is not included in legislation, student and parent opinions are usually sought in relation to school development and improvement activities, the work of the school principals (Tüzün and Sarışık, 2015) and in the evaluation of teacher performance (MoNE, 2018).

Student participation is also provided through school councils. Student councils are expected to convey student opinions on matters such as psychological counselling, guidance services, social activities, discipline, and strategic planning and development. However, research indicates that students are almost entirely excluded from input into the teaching-learning process (Tüzün and Sarışık, 2015).

Both the classroom representative and president of the school student council are elected. The presidents of the school student council select the district student representatives who make up the provincial student council. Student council presidents are chosen from each province and elect the president of the student council of Turkey (Aksoy, 2011). However, despite this elaborate representative structure, within schools, student councils work within strict limitations in terms of 
enabling students to participate in decision-making. To make these councils more effective, a much clearer set of roles and rights need to be elaborated (Tüzün and Sarışık, 2015).

The participation of families was legislated through the creation of parent-teacher associations under the framework of the 16th article of the Basic Law of National Education no. 1739 (MoNE, 2012). To improve education and training activities in schools, parent-teacher associations can raise in-kind and in-cash donations. Also, parent-teacher associations can organise social/cultural activities and operate or rent locations such as cantinas, open areas and saloons (Yolcu, 2011). Apart from parent-teacher associations, parents can participate in education through SSE in those schools which conduct internal evaluation. The opinions of parents are gathered through surveys which include questions on teacher performance, representing an uncommon power for parent voices which is not to be found in most SSE systems.

\section{DEAP supports and barriers in case study countries}

Supports. While legal regulations and guidelines can encourage and structure the process of DEAPS, it is clear that continuing professional development supporting evaluation capacity-building is an additional key requirement (Young et al., 2018). Of the countries studied, examples of support structures are found only in Ireland, where the national guidelines for SSE recommend that students and parents are involved as informants in the SSE process but give little guidance on how this could be facilitated. In 2010, the Professional Development Service for Teachers (PDST) was established to provide various support services such as leadership training, teacher development, school development planning, literacy and mathematics improvement, and the use of technology in education. More recently, schools can request support in conducting SSE (PDST, 2018), and the support services have developed a detailed programme of training. The inspectorate also provides advice and support, as do some university education departments. These supports, while considerable, tend not to place much focus on parent and student involvement. In the other three countries, supports are limited mainly to the provision of policies and practice guidelines rather than the provision of detailed training aimed at those with roles in the SSE process.

Barriers. As will be clear at this stage, the involvement of parents and students in the evaluation of schools is, to a greater or lesser degree, a common policy thread across the countries studied. Equally, each country has in place some mechanisms to enable this to happen in practice. However, the literature from each country tends to be critical of the extent to which much of significance is happening in this space, and reasons both practical and what also might be described as cultural are advanced to explain this rhetoric/ reality gap. We will look briefly at some of these.

A recent study of 13 European countries indicated that while in theory Portugal was one of the most open to parental involvement, it has, in fact, one of the lowest levels of actual participation (Gonçalves, 2017). Similarly, as noted already, levels of participation are also low in Ireland. According to the Portuguese research, parents do not participate, either because they do not know about parent representatives or do not know how to get in touch with them. In Ireland, it is noteworthy that while both parents and students have a role in school evaluation, little information about the outcome is provided to them. For example, not all parents receive school inspection reports or are told where to access them, while students complain that their contact with inspectors during inspection is the last they ever hear about the evaluation.

Moreover, meetings between inspectors and students are held in the presence of a non-participating teacher - something more likely to inhibit the student voice rather than encourage it (Dillon, 2012). In Turkey something similar applies, where parents are asked to complete perception scales (where the weighting of their responses is 5\% of the total) but then hear little if anything more 
about the outcome. In Belgium, it is challenging to research the overall picture as it varies a great deal from school to school, but there is nothing to suggest that the actuality is markedly different from the other three countries. In summary, research in Ireland seems to be reflective of the overall experience of the partner countries in that both parents and students feel 'disenfranchised' from school evaluation and that the process is 'insignificant to them' (Dillon, 2012: 12).

Of course, there are practical reasons for this exclusion. As we have seen above, despite rhetoric to the contrary, few supports to involving parents and students exist in the countries studied, with the possible exception of Ireland. Just as importantly, often parents and students are busy and unwilling to invest time. Many do not have the experience or capacity to play such a role and are happy to leave it to the 'experts'. Involving stakeholder groups in an in-depth manner also has resource implications. Inspection is a costly business, and consulting parents and students lengthens the process and takes up inspectorate time. Likewise, in conducting SSE schools have to use considerable resources to survey parents, run meetings and focus groups, drum up interest and disseminate findings.

However, there appears to be more than practicalities involved. There are also questions of culture. In schools in Ireland where no student council exists, Lodge and Lynch (2000) noted a fear among staff that such a development would lead to 'anarchy'. Teachers expressed concern about losing their authority, and teachers and principals frankly doubted that parents and students were informed or interested enough to make unbiased decisions for the good of the school. Improving the ways students and parents engage in school inspections will, according to the Irish chief inspector, be 'challenging' (Hislop, 2017: 20).

Although there is no direct evidence, it is, perhaps, reasonable to suspect that similar ambivalence may exist in other countries.

\section{Discussion and conclusion}

In the case of external evaluation, both students and parents participate in both Ireland and Portugal via questionnaires and focus groups. However, there is no significant role for students and parents in external school evaluations in Turkey, while similarly, in Belgium, although they are assured of participatory roles in school policymaking, students and parents have no legal representation in the evaluation of schools.

SSE is mandatory in Ireland, Portugal and Turkey, while in Belgium the autonomy afforded to schools means that there are no stipulations as to how schools should self-evaluate. Consequently, there is variation among schools in the execution of internal evaluations and it is up to individual schools in Belgium to decide on how they include and integrate students and parents. In Turkey, while SSE is compulsory, students and parents are only consulted via attitudinal surveys, while in Ireland and Portugal the extent and method of involving them is mostly left to each school to decide. Ireland and Portugal appear from official policy documentation to be most inclusive of stakeholders, with school inspection reports published online so that they are accessible to the whole school community. The stakeholder voice in Turkey is somewhat limited, and ambiguously included in Belgium.

In practice, all four countries have underdeveloped mechanisms to facilitate DEAPS. In the cases of Ireland and Portugal, for example, stakeholders are included in the official discourse of school evaluation but are often excluded from any meaningful involvement. This is perhaps due to societal and cultural traditions in both countries, where students and parents are traditionally isolated from school decision-making processes. O'Brien et al. (2019) point out that required participation rates of students and parents in the SSE process are not clearly defined while they are set out in detail with respect to administrators and teachers. Thus, it can reasonably be argued that meaningful distributed evaluation and planning strategies that have a real impact on student 
achievement have yet to come to full fruition in any of the countries studied. In fact, the student/ parent voice agenda remains at best aspirational and mostly tokenistic. Can the gap between policy and practice in this regard be closed?

To move beyond the rhetoric of parent and student voice in SSE, the literature suggests that a supportive and non-judgemental environment based on mutual trust and respect between stakeholders needs to be established and maintained and that both school leadership and training for the involved parties will prove beneficial. For example, many scholars see school principals as playing a key role in shaping successful parent-school relationships (see, for example, Barr and Saltmarsh, 2014; Gordon and Seashore Louis, 2009; Rapp and Duncan, 2012), and positive relations as being integral to and a consequence of student voice (see, for example, Cook-Sather, 2002; Mager and Nowak, 2012; Smyth, 2006). For example, to better include parents, LaRocque et al. (2011) recommend that schools could request specific forms of involvement from parents, while Murray et al. (2014) suggest that schools could implement more reliable and timely methods of communication such as utilising social media, scheduling school meetings and events at varied or multiple times, and soliciting parents' ideas on ways to overcome work- and scheduling-related barriers. In the case of students, Rudduck (2006: 142) outlines a set of basic guidelines for schools that help to define specific conditions in which student consultation can flourish:

- Reassuring all parties that consulting pupils and strengthening their participation are recognised nationally as legitimate moves;

- Building support among teachers by presenting evidence of the positive outcomes of consultation;

- Being sensitive to the anxiety experienced by teachers who have not before consulted pupils about teaching and learning;

- Making time for consultations;

- Ensuring that consultation is pursued through a range of avenues and not seen as something simply for a school council;

- Giving student voice a central place in school self-evaluation;

- Ensuring that newly appointed teachers understand the potential of consultation and feel confident about developing it.

What might be particularly useful for schools in moving beyond the rhetoric of parent and student voice in SSE, is Ravn's (1998) model of 'Joint Acting', a process of enabling all education stakeholders to share ideas in an environment of mutual respect, that ensures a logical, reasoned communication process. According to Ravn (1998: 377), 'Joint Acting ensures that no single party continuously determines the ideas that form the basis of discussions or actions in education.' It recognises four fundamental functions, each of which can best be explained by questions related to patterns of interaction:

1. The expressive function: what opportunities exist for the people involved to express themselves? Is there time for everyone's ideas to emerge?

2. The social function: what opportunities exist for enjoying a common experience? For people getting to know each other? To take planned action? To feel a sense of belonging?

3. The informative function: what opportunities do people have to exchange sufficient and high quality information on equally valued terms? To generate common and complementary knowledge? To share useful information with other educators and parents?

4. The controlling function: what are the opportunities for the people involved to equally influence the proposed plans? (Ravn, 1998: 377). 
Joint Acting requires various ways of meeting and making decisions about education, and requires that everyone understand and agree upon four key areas (Ravn, 1998: 377): content (the focus of parent-teacher discussions, which must be significant to the participants - that is, children's learning); structure and organisation (the ways that meetings and consultations are conducted to ensure dialogue and mutual assistance); intentions and possibilities (why particular topics are discussed, decisions are made and actions are taken); and benefits (who gains from the interactions and partnership activities). Drawing on the scholarship on student and parent voice, this Erasmus + project will design and provide a toolkit and a massive open online course (MOOC) for stakeholders to enable them to better facilitate distributed evaluation and planning in schools, while an accredited module for Initial Teacher Education (ITE) programmes across Europe will also be produced to better equip future generations of teachers.

While this Erasmus + project is expected to yield positive results, it would also be reasonable to suggest that a meaningful student and parent voice can only be empowered through the implementation of already declared policy to develop supportive reciprocal partnerships between parents/ students and teachers/school leaders/inspectors, each with clearly defined roles and responsibilities. In striving for enhanced stakeholder involvement in distributed evaluation and planning, greater legal recognition of the rights and roles that key stakeholders such as students and parents should exercise in school decision-making, and legal requirements for inspectors and schools to consult with these stakeholders via both external evaluation and SSE, are required. Fundamentally more problematic, however, may well be the change of culture necessary to accept that the concept of 'stakeholders' is not just the latest fad but rather that parents and students are in fact partners who have a right to full involvement and may bring a lot to the table if invited.

\section{Declaration of conflicting interests}

The authors declared no potential conflicts of interest with respect to the research, authorship and/or publication of this article.

\section{Funding}

The authors disclosed receipt of the following financial support for the research, authorship, and/or publication of this article: The authors wish to acknowledge that this research was made possible by funding through the Erasmus ${ }^{+}$project: Distributed Evaluation and Planning in Schools (DEAPS) (Grant No. 2017-1-IE01KA201-025693).

\section{ORCID iDs}

Martin Brown (iD) https://orcid.org/0000-0002-5436-354X

Craig Skerritt (iD https://orcid.org/0000-0002-3695-758X

\section{References}

Adelman H and Taylor L (2007) Systemic change for school improvement. Journal of Educational and Psychological Consultation 17(1): 55-77.

Aksoy MM (2011) Öğrenci meslicleri nedir? 13 Nisan 2018 tarihinde [What is a Childrens Council]. Available at: https://ogrencimeclisi.wordpress.com/ sitesinden alınmıştır (accessed 13 April 2018).

Aydın İ (2013) Ögrretimde denetim (Supervision in education). 4th edn. Ankara: Pegem Akademi.

Barr J and Saltmarsh S (2014) 'It all comes down to the leadership': The role of the school principal in fostering parent-school engagement. Educational Management Administration \& Leadership 42(4): 491-505.

Başaran İE and Çınkır Ş (2013) Türk eğitim sistemi ve okul yönetimi (Turkish education system and school management). Ankara: Siyasal Kitabevi. 
Beckmann A, Cooper C and Hill D (2009) Neoliberalisation and materialisation of 'education' in England and Wales - a case for reconstructing education. Journal for Critical Education Policy Studies 7(2): 311-345.

Bowen GA (2009) Document analysis as a qualitative research method. Qualitative Research Journal 9(2): $27-40$.

Borkan J (1999) Immersion/crystallisation. In: Crabtree BF and Miller W (eds) Doing Qualitative Research. 2nd edn. London: SAGE, pp.179-194.

Brown M (2013) Deconstructing evaluation in education: The case of Ireland. PhD Thesis, Dublin City University. Available at: http://doras.dcu.ie/19382/ (accessed 12 March 2018).

Brown M, McNamara G and O'Hara J (2016a) Quality and the rise of value-added in education: The case of Ireland. Policy Futures in Education 14(6): 810-829.

Brown M, McNamara G, O'Hara J, et al. (2016b) Exploring the changing face of school inspections. Eurasian Journal of Educational Research (66): 1-26. https://doi.org/10.14689/ejer.2016.66.1

Brown M, McNamara G, O'Hara J, et al. (2017) Striking a balance? The continuing evolution of Inspection and school self-evaluation in Ireland. In: Baxter J (ed.) School Inspectors: Operational Challenges in National Policy Contexts. London: Springer, pp. 71-96.

Brown M, McNamara G, O’Hara J, et al. (2018) Integrated co-professional evaluation? Converging approaches to school evaluation across frontiers. Australian Journal of Teacher Education 43(12): 76-90.

Byrne D and Smyth E (2011) Behind the Scenes? A Study of Parental Involvement in Post Primary Education. Dublin: Economic and Social Research Institute.

Carrington S and Robinson S (2006) Inclusive school community: Why is it so complex? International Journal of Inclusive Education 10: 323-334.

Carroll M (2007) One more time: What is supervision? Journal of Psychotherapy in Australia 13(3): 34-40.

Cautreels P and Van Petegem P (2006) Ik zie, ik zie wat jij niet ziet. Collegiale visitatie als hefboom voor schoolontwikkeling (I see, I see what you can't see: Collegial visits as a catalyst for school development). Mechelen: Wolters Plantyn.

Cook-Sather A (2002) Authorizing students' perspectives: Toward trust, dialogue, and change in education. Educational Researcher 31(4): 3-14.

Cosgrove J and Gilleece L (2012) An international perspective on civic participation in Irish post-primary schools: Results from ICCS. Irish Educational Studies 31(4): 377-395.

Çınkır Ş (2014) Çeşitli ülkelerde eğitim denetimi ve müfettişlerin eğitimi, seçim ve atama ölçütleri (Educational supervision and training, selection and appointment of supervisors in various countries). In: From past to future educational supervision and supervisorship panel, Bilkent University, Turkey, 18 December.

Darmody M and Smyth E (2013) Governance and Funding of Voluntary Secondary Schools in Ireland. Dublin: Economic and Social Research Institute.

Department of Education and Skills (2012a) Circular 0040/2012, Implementation of school self-evaluation - post primary.

Department of Education and Skills (2012b) Circular 0040/2012, Implementation of school self-evaluation - primary.

Department of Education and Skills (2016) A Guide to Inspection in Post-Primary Schools. Dublin: Stationery Office.

Dillon S (2012) 'The way I see it is . .'? Whole-school evaluation in Irish post-primary schools from the perspectives of principals, teachers, parents and students. $\mathrm{PhD}$ Thesis, Dublin City University, Ireland.

Donaldson G (2013) The SICI Bratislava memorandum on inspection and innovation. Available at: http:// www.sici-inspectorates.eu/About-us/Vision-mission/The-Bratislava-Memorandum-is-on-the-Website (accessed 20 October 2017).

European Commission (2015) Assuring Quality in Education: Policies and Approaches to School Evaluation in Europe. Luxembourg: Publications Office of the European Union.

Faddar J and Vanhoof J (2018) Country Background Report Belgium (Flemish Community) on Distributed Evaluation And Planning in Schools. Antwerp: University of Antwerp.

Figueiredo M, Ramalho H and Rocha J (2018) Country Background Report on Distributed Evaluation and Planning in Portuguese Schools. Viseu: Instituto Politecnico De Viseu. 
Fleming B (2016) Irish Education, 1922-2007: Cherishing All the Children? Dublin: Createspace Independent Publishing Platform.

Fleming D (2011) Student voice in Irish post-primary schools: Is the challenge too challenging? The Boolean, $66-70$.

Fleming D (2015) Student voice: An emerging discourse in Irish education policy. International Electronic Journal of Elementary Education 8(2): 223-242.

Gilleece L and Eivers E (2018) Primary school websites in Ireland: How are they used to inform and involve parents? Irish Educational Studies 37(4): 411-430.

Glickman CD, Gordon SP and Ross-Gordon JM (2014) Denetim ve öğretimsel liderlik: Gelişimsel bir yaklaşım [SuperVision and Instructional Leadership: A Developmental Approach]. Ankara: Ani Publishing.

Gonçalves E (2017) Parents' involvement and participation in Portugal. The European Conference on Educational Research, Reforming Education and the Imperative of Constant Change, Copenhagen, 24 August.

Gordon MF and Seahshore Louis K (2009) Linking parent and community involvement with student achievement: Comparing principal and teacher perceptions of stakeholder influence. American Journal of Education 116(1): 1-31.

Hannes M and Vanhoof S (2017) De school door de bril van lokale partners. Het stakeholdersoverleg als platform voor kwaliteitszorg [The school through the lens of local partners: Stakeholder meetings as a platform for quality assurance]. In: Vanhoof J and De Ruytter G (eds) De rol van externen bij kwaliteitszorg [The role of external parties in quality assurance]. Brussels: Politeia, pp. 115-130.

Hart RA (1992) Children's participation: From tokenism to citizenship. Florence: UNICEF.

Hislop H (2017) A co-professional approach to inspection for accountability and improvement: Progress and prospects in the Irish context. Inaugural Public Lecture to mark the incorporation of the Centre for Evaluation, Quality and Inspection within the DCU Institute of Education, Dublin, 11 May.

Hooge E, Burns T and Wilkoszewski H (2012) Looking beyond the numbers: Stakeholders and multiple school accountability. OECD Education Working Papers No. 85. OECD Publishing.

Katipoğlu İ (2016) Ministry of national education supervisors' adoption level of risk-based supervision model and the consideration of its applicability at schools. Eurasian Journal of Educational Research 66: 407-428.

LaRocque M, Kleiman I and Darling SM (2011) Parental involvement: The missing link in school achievement. Preventing School Failure 55(3): 115-122.

Law no. 31/2002, of 20 December - approves the evaluation system for non-higher education, developing the regime foreseen in the Law no. 46/86, of 14 October (Comprehensive Law on the Education System) (together with Decree-Law no. 75/2008, 22nd April, amended by Decree-Law no. 137/2012, 2nd July).

Lodge A and Lynch K (2000) Power: a central educational relationship. Irish Educational Studies 19(1): 46-67.

McNamara G and O'Hara J (2012) From looking at our schools (LAOS) to whole school evaluation-management, leadership and learning (WSE-MLL): The evolution of inspection in Irish schools over the past decade. Educational Assessment, Evaluation and Accountability, 24(2): 79-97.

Mager U and Nowak P (2012) Effects of student participation in decision making at school. A systematic review and synthesis of empirical research. Educational Research Review 7(1): 38-61.

Ministry of National Education (1995) Millî Eğitim Bakanllğı Millî Eğitim Müdürlükleri Yönetmeliği [Ministry of National Education Directorates regulation]. Available at: "http://mevzuat.MoNE.gov.tr/ html/2424_00.html (accessed 9 April 2018).

Ministry of National Education (2012) Basic Law of National Education no. 1739. Ankara: Ministry of Education.

Ministry of National Education (2014) Milli Eğitim Bakanlığına Bağlı Eğitim Kurumları Yöneticilerinin Görevlendirilmelerine İlişkin Yönetmelik [MoNE regulation on administrators of the educational institutions] (accessed 12 March 2019).

Ministry of National Education (2018) MEB Öğretmen Performans Değerlendirme Yönetmelik Taslağ1 [MoNE Teacher performance evaluation regulation draft]. Available at: https://www. memurlar. net/haber/730414/meb-ogretmen-performans-degerlendirme-yonetmelik-taslagini-goruse-acti.html (accessed 13 April 2018). 
Murray KW, Finigan-Carr N, Jones V, et al. (2014) Barriers and facilitators to school-based parent involvement for parents of urban public middle school students. SAGE Open 4(4): 1-12.

O'Brien S, McNamara G, O'Hara J, et al. (2019) Irish teachers starting on a journey of data use for school self-evaluation. Studies in Educational Evaluation 60: 1-13.

Office for Economic Co-operation and Development (2019) Education policy country snapshots. In: Education Policy Outlook 2019: Working Together to Help Students Achieve their Potential. Paris: OECD Publishing, pp. 259-595.

Professional Development Service for Teachers (2018) Professional development service for teachers background information. Available at: http://www.pdst.ie/about_us (accessed 23 November 2018).

Rapp N and Duncan H (2012) Multi-dimensional parental involvement in schools: A principal's guide. International Journal of Educational Leadership Preparation 7(1): 1-14.

Ravn B (1998) Involving parents in school decision-making: Formal and informal parental involvement in school. Childhood Education 74(6): 375-377.

Rudduck J (2006) The past, the papers and the project. Educational Review 58(2): 131-143.

Santiago P (2013) Trends in evaluation and assessment. In: Nusche D, Radinger D, Santiago P, et al (eds) OECD Review on Evaluation and Assessment in Education: Synergies for Better Learning: An International Perspective on Evaluation and Assessment. Paris: OECD Publishing, pp.35-57.

Skerritt C (2019a) Privatization and 'destatization': School autonomy as the 'Anglo neoliberalization' of Irish education policy. Irish Educational Studies 38(2): 263-279

Skerritt C (2019b) 'I think Irish schools need to keep doing what they're doing': Irish teachers' views on school autonomy after working in English academies. Improving Schools 22(3): 267-287.

Smyth J (2006) Educational leadership that fosters 'student voice'. International Journal of Leadership in Education 9(4): 279-284.

Sousa AB and Terrasêca MM (2015) Processos de autoavaliação de escolas ou avaliação interna do sistema? (Schools self-evaluation processes or internal evaluation of the system?). Arquivos Analíticos de Políticas Educativas 23(115). http://dx.doi.org/10.14507/epaa.v23.2085

Taymaz H (2013) Eğitim sisteminde teftiş kavramlar ilkeler yöntemler (Supervision in education system: Concepts, principles and methods). 10th edn. Ankara: Pegem Akademi.

Tüzün I. and Sarışık Y (2015) Türkiye'de Okullarda Çocuk Katılımı: Durum Analizi (Participation of children at schools in Turkey: A case analysis). İstanbul: İstanbul Bilgi Üniversitesi Yayınları.

Vanhoof J, Deneire A and Van Petegem P (2011) Waar zit beleidsvoerend vermogen in (ver)scholen? Aanknopingspunten voor zelfevaluatie en ontwikkeling (Where is policymaking capacity hidden in schools? Cruxes for self-evaluation and development). Mechelen: Plantyn.

Vanhoof J, Van Petegem P and De Maeyer S (2009) Attitudes towards school self-evaluation. Studies in Educational Evaluation 35: 21-28.

Verger A and Curran M (2014) New public management as a global education policy: Its adoption and recontextualization in a Southern European setting. Critical Studies in Education 55(3): 253-271.

Yolcu H (2011) Türkiye'de Eğitimde Yerelleşme ve Ailelerin Okul Yönetimine Katılımının Güçlendirilmesi: Değişen Ne? (Localisation and empowering the participation of parents in school management in Turkey). Kuram ve Uygulamada Eğitim Bilimleri 11(3): 1229-1251.

Young C, McNamara G, Brown M, et al. (2018) Adopting and adapting: school leaders in the age of datainformed decision making. Educational Assessment, Evaluation and Accountability 30(2): 133-158.

\section{Author biographies}

Martin Brown is research director at EQI - The Centre for Evaluation Quality and Inspection, School of Policy and Practice, DCU Institute of Education, Ireland.

Gerry McNamara is professor of Education and a director of EQI - The Centre for Evaluation Quality and Inspection, School of Policy and Practice, DCU Institute of Education, Ireland.

Sakir Cinkir is an associate professor at the Department of Educational Administration and Policy, Ankara University, Turkey. 
Jerich Fadar is a postdoctoral researcher at the Department of Training and Education Sciences of the Faculty of Social Sciences at the University of Antwerp.

Maria Figueiredo is a lecturer at the School of Education, Polytechnic Institute of Viseu, Portugal.

Jan Vanhoof is is an associate professor on the staff of the Department of Training and Education Sciences of the University of Antwerp (Faculty of Social Sciences).

Joe O'Hara is professor of Education and a director of EQI - The Centre for Evaluation Quality and Inspection, School of Policy and Practice, DCU Institute of Education, Ireland.

Craig Skerritt is policy and international programmes manager at the Royal Irish Academy and doctoral research scholarship recipient at the School of Policy and Practice, DCU Institute of Education, Ireland.

Shivaun O'Brien is a senior researcher at EQI - The Centre for Evaluation Quality and Inspection and director of school at placement at the School of Policy and Practice, DCU Institute of Education, Ireland.

Gül Kurum, PhD, is a researcher and lecturer at the Faculty of Education, Department of Educational Administration at Trakya University, Edirne, Turkey.

Henrique Ramalho is a lecturer at the School of Education, Polytechnic Institute of Viseu, Portugal.

João Rocha is a lecturer at the School of Education, Polytechnic Institute of Viseu, Portugal. 